\title{
Emerging pests and diseases threaten Eucalyptus camaldulensis plantations in Sardinia, Italy
}

Antonio Deidda, Franco Buffa, Benedetto Teodoro Linaldeddu, Claudia Pinna, Bruno Scanu, Vitale Deiana, Alberto Satta, Antonio Franceschini, Ignazio Floris

\begin{abstract}
The rapid growth and environmental adaptability of Eucalyptus species has favored their global cultivation for pulpwood production. On the island of Sardinia, Italy, eucalypt plantations were established in the $20^{\text {th }}$ century primarily in areas reclaimed from marshland, but the trees are now grown all over the island as ornamentals or windbreaks, and for timber, pulp and honey production. In recent years, an unusual decline and mortality of unknown etiology has been observed in Eucalyptus camaldulensis (river red gum) plantations throughout the island. Given the ecological and economic importance of eucalypt ecosystems in Sardinia, a survey was carried out in 2013 to determine which insect pests and fungal pathogens are directly involved in these phenomena. Field surveys throughout the island revealed severe infestations with the red gum lerp psyllid (Glycaspis brimblecombei) at all 12 surveyed sites, with the greatest numbers of pre-imaginal stages and adults occurring between May and July. The adult population reached its peak in July, followed 2 months later by the peak population of its specific parasitoid, Psyllaephagus bliteus. Symptoms of leaf chlorosis, crown thinning, shoot and branch dieback, sunken cankers, epicormic shoots and exudations of kino gum were also observed at the 12 field sites. Symptomatic woody samples yielded fungal isolates representing three distinct families: Botryosphaeriaceae, Diaporthaceae and Valsaceae. Morphological and DNA sequence data revealed seven distinct fungal species, namely Diaporthe foeniculina, Neofusicoccum australe, N. Iuteum, $N$. mediterraneum, $N$. parvum, $N$. vitifusiforme and Valsa fabianae. Two putative new species of Cytospora were also identified. Neofusicoccum australe was the only species recovered from all 12 sites, with isolation frequencies of 51-95\%. Pathogenicity trials revealed that all Neofusicoccum species except $N$. vitifusiforme are directly involved in the etiology of the observed decline in the $E$. camaldulensis population on Sardinia.
\end{abstract}

Keywords: Timber Industries, Exotic Species, Biosecurity, Invasive Pathogens and Insects tural timber, pulp and fuel-wood (Flynn 2010).

In Italy, eucalypt plantations cover more than 72,000 ha. The most common species are Eucalyptus camaldulensis Dehnh., E. globulus Labill. and E. occidentalis Endl. The massive introduction of these exotic species began in the first half of the $20^{\text {th }}$ century to protect areas affected by soil erosion and to produce pulpwood for the paper industry (Boggia 1987, Mercurio \& Mi-
Dipartimento di Agraria, Sezione di Patologia vegetale ed Entomologia, Università degli Studi di Sassari, v.le Italia 39, I-07100 Sassari (Italy)

@ Benedetto Teodoro Linaldeddu (ben@uniss.it)

Received: Aug 11, 2015 - Accepted: Mar 05, 2016

Citation: Deidda A, Buffa F, Linaldeddu BT, Pinna C, Scanu B, Deiana V, Satta A, Franceschini A, Floris I (2016). Emerging pests and diseases threaten Eucalyptus camaldulensis plantations in Sardinia, Italy. iForest 9: 883-891. - doi: 10.3832/ifor1805-009 [online 2016-06-29]

Communicated by: Alberto Santini island of Sardinia were estimated to cover 8000-8700 hectares (Mercurio \& Minotta 2000), but more recent investigations as part of a Sardinian regional program (Buffa 2015) provided a more accurate quantification of the area covered by plantations of at least 1 ha, revealing a total of 22,754 ha, $90 \%$ of which are less than $400 \mathrm{~m}$ above sea level. These were established initially in areas reclaimed from marshland but have subsequently spread all over the island. The trees are cultivated as windbreaks and ornamentals, for the production of pulpwood, biomass and construction timber, and more recently for the production of honey.

Over the last few decades, several insect pests and fungal pathogens have threatened Eucalyptus species in both native and introduced ranges (Ohmart \& Edwards 1991, Crous \& Wingfield 1997, Wingfield et al. 2008, Branco et al. 2014). In Australia, where forests and woodlands are dominated by eucalypts, several research teams have investigated the prevalent insect 
pests, whereas studies of exotic plantations have usually focused on the insects of greatest economic importance. The massive introduction of eucalypts into new environments has created problems with exotic pests, including indigenous insects that have adapted to feed on these new hosts. Recent invasions of exotic species have been reported, including sap-sucking insects such as Glycaspis brimblecombei Moore, Blastopsylla occidentalis Taylor and Thaumastocoris peregrinus Carpintero \& Dellapé (Brennan \& Gill 1999, Wilcken et al. 2010, Tamesse et al. 2010). Other investigations have considered the gall wasps Ophelimus maskelli Ashmead and Leptocybe invasa Fisher \& La Salle, as well as beetles such as Phoracantha semipunctata Fabricius, P. recurva Newman and Gonipterus scutellatus Gyllenhal (Paine \& Millar 2002, EPPO 2006).

Glycaspis brimblecombei, the red gum lerp psyllid, is considered the most serious pest of eucalypts in the Mediterranean area (Bella \& Rapisarda 2013, Reguia \& PerisFelipo 2013, Ben Attia \& Rapisarda 2014, Spodek et al. 2015) and E. camaldulensis Dehnh. is the most susceptible to infestation (Brennan et al. 2001). Glycaspis brimblecombei was first detected in Italy in 2010 (Laudonia \& Garonna 2010) and quickly spread through the central-southern areas including Sicily and Sardinia. Eggs are laid on the leaf surface, and the developing nymphs form conical white covering structures (lerps) from lipids, proteins and carbohydrates, and live under the protective structure where they feed by penetrating the vascular tissues and withdrawing sap (Sharma et al. 2013). Adults and nymphs also produce large amounts of honeydew, promoting the growth of sooty mold. The resulting damage includes leaf discoloration and, in the case of heavy infestations, severe leaf drop. Psyllaephagus bliteus Riek (Hymenoptera Encyrtidae) is a specific natural enemy of $G$. brimblecombei and develops solely on this host (Paine et al. 2000, Daane et al. 2005). It is present in Italy and has been used for classical biological control strategies (Caleca et al. 2011).

One of the most serious diseases affect- ing eucalypt trees worldwide is Mycosphaerella leaf disease (MLD), which represents a substantial economic threat to commercial plantations (Crous et al. 2007b, Wingfield et al. 2008, Branco et al. 2014). The predominant symptoms of MLD are leaf spots that often enlarge and coalesce to form blotches on the leaf surface, causing leaf blight, premature defoliation and shoot dieback, and stunting (Lundquist \& Purnell 1987).

Other severe diseases that pose a threat to eucalypt plantations worldwide include eucalypt rust caused by Puccinia psidii G. Winter, Ceratocystis wilt caused by Ceratocystis spp., certain canker-causing agents such as Chrysoporthe cubensis (Bruner) Hodges (= Cryphonectria cubensis), and species of Botryosphaeriaceae Theiss. \& P. Syd. (Coutinho et al. 1998, Gryzenhout et al. 2004, Roux \& Wingfield 2009, Slippers et al. 2009). The wide distribution and virulence of the latter cause the greatest negative impact on eucalypt trees both in native and introduced ranges (Slippers et al. 2004, Burgess et al. 2005, Mohali et al. 2007). Several studies have revealed the involvement of some species belonging to the genera Botryosphaeria, Lasiodiplodia and Neofusicoccum in the decline and mortality of Eucalyptus spp. In particular, Botryosphaeria dothidea (Moug.: Fr.) Ces. \& De Not. and Neofusicoccum ribis (Slippers, Crous \& M.J. Wingf.) Crous, Slippers \& A.J.L. Phillips have been commonly associated with different disease symptoms affecting Eucalyptus spp. in temperate climates (Webb 1983, Old et al. 1990, Smith et al. 1994), while Lasiodiplodia theobromae (Pat.) Griffon \& Maubl. was the species most frequently reported in tropical areas (Sharma et al. 1984, Roux et al. 2001, Mohali et al. 2005). However, recent studies based on DNA sequence data have revealed that several strains previously identified as $B$. dothidea and $N$. ribis are in fact strains of N. parvum (Slippers et al. 2004). Furthermore, several cryptic species have been identified within the $L$. theobromae species complex and four species are currently known to infect eucalypt trees, namely L. crassispora T.I. Burgess \& Barber, L.

Tab. 1 - Characteristics of the Eucalyptus camaldulensis plantation survey sites.

\begin{tabular}{cllrrr}
\hline Site & Locality & Latitude (N) & Longitude (E) & $\begin{array}{c}\text { Elevation } \\
\text { (m a.s.l.) }\end{array}$ & $\begin{array}{c}\text { Type of } \\
\text { plantation }\end{array}$ \\
\hline 1 & Ottana & $40^{\circ} 13^{\prime} 56.82^{\prime \prime}$ & $9^{\circ} 01^{\prime} 54.02^{\prime \prime}$ & 185 & Windbreak \\
2 & Arborea & $39^{\circ} 48^{\prime} 06.43^{\prime \prime}$ & $8^{\circ} 37^{\prime} 47.20^{\prime \prime}$ & 7 & Plantation \\
3 & Serramanna & $3^{\circ} 2^{\prime} 48.38^{\prime \prime}$ & $8^{\circ} 51^{\prime} 46.14^{\prime \prime}$ & 30 & Windbreak \\
4 & Uta & $39^{\circ} 15^{\prime} 24.84^{\prime \prime}$ & $8^{\circ} 55^{\prime} 50.54^{\prime \prime}$ & 6 & Plantation \\
5 & Siliqua & $39^{\circ} 16^{\prime} 16.32^{\prime \prime}$ & $8^{\circ} 48^{\prime} 52.57^{\prime \prime}$ & 66 & Plantation \\
6 & San Vito & $39^{\circ} 20^{\prime} 03.84^{\prime \prime}$ & $9^{\circ} 31^{\prime} 51.35^{\prime \prime}$ & 13 & Windbreak \\
7 & Arbatax & $39^{\circ} 55^{\prime} 42.07^{\prime \prime}$ & $9^{\circ} 42^{\prime} 30.31^{\prime \prime}$ & 13 & Ornamental \\
8 & Siniscola & $40^{\circ} 35^{\prime} 27.70^{\prime \prime}$ & $9^{\circ} 42^{\prime} 34.52^{\prime \prime}$ & 39 & Plantation \\
9 & Olbia & $40^{\circ} 52^{\prime} 14.61^{\prime \prime}$ & $9^{\circ} 30^{\prime} 55.81^{\prime \prime}$ & 15 & Windbreak \\
10 & Ozieri & $40^{\circ} 36^{\prime} 48.18^{\prime \prime}$ & $8^{\circ} 55^{\prime} 49.95^{\prime \prime}$ & 390 & Windbreak \\
11 & S. Maria La Palma & $40^{\circ} 39^{\prime} 09.62^{\prime \prime}$ & $8^{\circ} 17^{\prime} 25.73^{\prime \prime}$ & 30 & Windbreak \\
12 & Alghero & $40^{\circ} 35^{\prime} 37.91^{\prime \prime}$ & $8^{\circ} 17^{\prime} 25.12^{\prime \prime}$ & 7 & Ornamental \\
\hline
\end{tabular}

pseudotheobromae A.J.L. Phillips, A. Alves \& Crous, L. rubropurpurea Burgess, Barber \& Pegg and L. theobromae (Burgess et al. 2006b, Alves et al. 2008, Slippers et al. 2009).

Despite the occurrence of pests and pathogens in other countries, neither insect pests nor serious fungal diseases were observed on eucalyptus plantations in Sardinia until 2010. Since then, beekeepers have reported a remarkable reduction in eucalyptus honey yields, which have been attributed to inflorescence damage caused by insects. Subsequent field surveys have demonstrated the pullulation of psyllid infestations and the widespread decline and mortality of young and mature E. camaldulensis trees, with unknown etiology.

Given the economic importance of eucalyptus plantations for the regional economy and the potential losses caused by these emerging pests and diseases, we set out to record the symptoms and study the etiology of the decline events in Sardinian eucalypt plantations, to determine the virulence of the major fungal pathogens, and to investigate the population dynamics of the prevalent insect pest $G$. brimblecombei and the role of its specific parasitoid P. bliteus.

\section{Materials and methods}

\section{Field surveys and sampling procedure}

Field surveys were carried out in spring, summer and autumn 2013, at 12 E. camaldulensis plantation areas throughout Sardinia (Tab. 1). Stem and branch cankers were the most frequent symptoms, so the agents responsible at each site and season were determined by selecting five declining trees and collecting samples on the stem or branches from the margin of three active cankers per tree, making a total of 510 cankers.

The adult G. brimblecombei population was sampled by placing four yellow sticky traps $(20 \times 20 \mathrm{~cm})$ in each study area from March to December. They were changed every 2 weeks and the number of adults was counted. To monitor P. bliteus parasitism, 16 leaves per station were randomly collected every 2 weeks. The number of unparasitized juvenile stages (neanids and nymphs) and mummies (parasitized nymphs) of G. brimblecombei were counted on the upper and lower side. The percentage of parasitism at each station was calculated as the ratio between the number of mummies and the total number of G. brimblecombei individuals (not taking into account the newly parasitized nymphs without symptoms, thus representing a conservative estimate). The susceptibility of second-instar G. brimblecombei psyllids to parasitism by $P$. bliteus is minimal due to the size of the lerps (Daane et al. 2005).

Isolation and identification of cankerassociated fungi

Eucalyptus samples were taken to the 
laboratory and the outer bark surface tissue was cut away with a scalpel. Longitudinal and transversal cuts from symptomatic branch samples revealed internal symptoms. Fungi were isolated from chips of inner bark and xylem tissue $\left(\sim 5 \mathrm{~mm}^{2}\right)$ removed from the margin of necrotic lesions with a sterile scalpel. All chips were cultured on potato dextrose agar (PDA, Oxoid Ltd., Basingstoke, UK) in Petri dishes. After incubation at $25^{\circ} \mathrm{C}$ for 5-7 days in the dark, fungal colonies were sub-cultured onto half-strength PDA supplemented with autoclaved holm oak twigs and incubated at room temperature with natural daylight until the differentiation of reproductive structures was observed. The contents of conidiomata were dissected, mounted in $100 \%$ lactic acid and observed at X400 magnification. Fungal isolates were assigned to groups according to morphological features and representative isolates from each group were used for DNA analysis and pathogenicity tests.

\section{DNA extraction, PCR amplification and sequencing}

Genomic DNA was extracted from 5-dayold cultures grown on PDA at $25^{\circ} \mathrm{C}$ using Instagene Matrix ${ }^{\circledR}$ (BioRad Laboratories, Hercules, California, USA). The entire internal transcribed spacer (ITS) region of the ribosomal DNA, including the 5.8S rRNA gene, was amplified and sequenced using primers ITS1 and ITS4 (White et al. 1990), whereas part of the $E F-1 \alpha$ gene encoding translational elongation factor 1 alpha was amplified and sequenced with primers EF446f and EF1035r (Inderbitzin et al. 2010). PCR amplification was carried out as described by Linaldeddu et al. (2013) and the products were purified using the EUROGOLD ${ }^{\circledast}$ gel extraction kit according to the manufacturer's instructions (EuroClone S.p.A., Pero, Italy). Both strands were sequenced by the BMR Genomics DNA sequencing service (http://www.bmr-geno mics.it). The nucleotide sequences were edited using FinchTV v. 1.4.0 (Geospiza, Inc., Seattle, Washington, USA; http:// www.geospiza.com/finchtv) and compared with sequences deposited in GenBank using the BLAST algorithm (http://blast. ncbi.nlm.nih.gov).

\section{Pathogenicity tests}

To verify the pathogenicity of each species investigated in this study, a field inoculation trial was conducted in May 2014 on asymptomatic E. camaldulensis trees located in a plantation in the south of Sardinia (Serramanna: $39^{\circ} 41^{\prime} 96^{\prime \prime} \mathrm{N}, 8^{\circ} 92^{\prime} 71^{\prime \prime}$ E). During the experimental period, the daily mean air temperature was $14.6-32.3{ }^{\circ} \mathrm{C}$ and the total rainfall was $0.4 \mathrm{~mm}$.

Six plants ( $15-20 \mathrm{~cm}$ trunk diameter) were inoculated at breast height with a representative isolate of each fungal species, and six uninfected plants were used as controls. The inoculated region of the trunk was surface-disinfected with $70 \%$ ethanol and a piece of outer and inner bark was removed with a flamed cork borer and replaced with an agar-mycelium plug taken from the margin of an actively growing colony on PDA. The original bark plug was placed on top of the agar disk and the inoculation site was covered with cotton wool soaked in sterile water and wrapped in a piece of aluminum foil secured with masking tape. Controls were inoculated with a sterile PDA plug applied as described above. After 1 month, the outer bark was carefully removed with a chisel and the necrotic lesion surrounding each inoculation site was measured by placing transparent paper over the top of the lesion and drawing around the perimeter. The image of each lesion was scanned and the area was determined using the Assess v. 2.0 software (Lamari 2002).

The re-isolation of inoculated species was attempted by transferring onto PDA 10 pieces of inner bark and wood taken from around the margin of each lesion. Cultures were grown in daylight and room temperature until the development of fungal colonies was observed.

\section{Statistical analysis}

Pathogenicity assay data were checked for normality, then subjected to analysis of variance (ANOVA). Significant differences among mean values were determined using Fisher's least significant differences multiple range test $(\alpha=0.05)$ after oneway ANOVA using the software package $\mathrm{XLSTAT}^{\oplus}$ (Addinsoft, Paris, France).

The abundance of $G$. brimblecombei and the prevalence of $P$. bliteus parasitism were analyzed using a two-factor design (station and month) general linear model of ANOVA, and means were separated by Fisher's least significant differences test.

\section{Results}

\section{Field surveys}

Glycaspis brimblecombei and its parasitoid $P$. bliteus were monitored at 12 field sites to characterize the population dynamics in each area. Glycaspis brimblecombei infestations were abundant at all the field sites on both declining and asymptomatic trees (Fig. 1). No significant differences were observed among the sites in terms of adult abundance $(F=1.60, d f=11, P=0.1097)$, preimaginal stage abundance $(F=0.84, d f=11$, $\mathrm{P}=0.5989$ ) or the level of parasitism $(\mathrm{F}=1.37, \mathrm{df}=11, \mathrm{P}=0.1999)$, thus mean values representing the data collected at all sites are presented in Fig. 2. There was a significant increase in the number of pre-imaginal $(F=27.29, d f=9, P<0001)$ and adult $G$. brimblecombei $(F=10.29, d f=9, P<0001)$ between May and July, followed by a decrease in the subsequent months. The sticky traps revealed a peak in the number of adults in July with a mean value of 26 specimens per trap per day. There was a strong correlation between the number of adult females caught in the sticky traps and the imma- ture stages on the foliage samples $(r>$ 0.90). The incidence of parasitism showed a bimodal trend, with the September value (52\%) significantly higher than all other months except October $(F=6.97, d f=9$, $\mathrm{P}<0.0001)$. Parasitism reached a peak 2 months after the peak population of preimaginal stage and adult G. brimblecombei.

Eucalyptus camaldulensis trees affected by decline and mortality were abundant at all the field sites, suggesting the phenomenon we observed was epidemic. Both young and old trees exhibited various canopy symptoms, including the progressive dieback of twigs and branches associated with the abnormal growth of epicormic shoots (Fig. 3). All declining trees showed extensive sunken cankers on the branches and trunk, often with copious exudations of kino gum. After removing the outer and inner bark from cankers, dark brown necrotic lesions were visible on the xylem tissue. When branch and trunk cankers were cross-sectioned, internal symptoms included characteristic wedge-shaped necrotic lesions which often interested a large part of the section (Fig. 3). Cankers and bark necrosis on branches and trunks spread from the top downwards. In correspondence of necrotic tissues a number of dark pycnidia erupting from the bark were usually visible.

\section{Isolation and identification of canker- associated fungi}

The symptomatic woody samples yielded 489 fungal isolates representing the families Botryosphaeriaceae, Diaporthaceae Höhn. ex Wehm. and Valsaceae Tul. \& C. Tul. Botryosphaeriaceous fungi were the dominant component, accounting for 391 of the isolates. On the basis of morphological features and DNA sequence data (ITS and $E F-1 \alpha$ ), five distinct species were identified, namely Neofusicoccum parvum (6 isolates), N. vitifusiforme (12 isolates), $\mathrm{N}$. luteum (14 isolates), N. mediterraneum (20 isolates) and N. australe (339 isolates). For each species BLAST searches against GenBank showed $99-100 \%$ identity to reference sequences of representative strains including those of ex-type cultures. New sequences were deposited in GenBank [accession numbers: KP142959 - KP142961 (ITS), KP142978 (EF-1a) for N. parvum; KP142962 - KP142966 (ITS), KP142979 (EF1a) for N. vitifusiforme; KP142949 - KP14 2953 (ITS), KP142976 (EF-1a) for N. luteum; KP142954-KP142958 (ITS), KP142977 (EF-1a) for N. mediterraneum; KP142944 - KP1429 48 (ITS), KP142975 (EF-1a) for N. australe]. Neofusicoccum australe was the only species recovered from all survey sites in all sampling seasons, 339 of the 510 cankers processed yielded colonies of this pathogen. The isolation frequency (number of cankers with positive isolations of each fungus divided by the total number of cankers examined $\times 100$ ) of $N$. australe ranged from $51 \%$ to $95 \%$ (Tab. 2). The other four Neofusicoccum species were isolated 



Fig. 1 - Life stages of Glycaspis brimblecombei. (a-d): Eggs, neanid, nymph and adult stage; (e): construction of a lerp on a Eucalyptus camaldulensis leaf; ( $f$ ): adult of the parasitoid Psyllaephagus bliteus; ( $\mathrm{g}$ ) leaves of Eucalyptus camaldulensis heavily infested with Glycaspis brimblecombei. with a lower frequency and were often found at only a few sites (Tab. 2). The isolation frequency of $\mathrm{N}$. australe declined between May and October, whereas N. mediterraneum showed an opposite trend. The other species were predominantly isolated in the spring (Tab. 2).
The remaining 98 isolates were found to represent four distinct species: Diaporthefoeniculina (Sacc.) D. Udayanga \& L.A. Castlebury (three isolates, GenBank KP1429 70), two unidentified Cytospora species (seven isolates of species 1, GenBank KP14 2967-KP142968; five isolates of species 2,
GenBank KP142969) and Valsa fabianae G.C. Adams, M.J. Wingf. \& Jol. Roux (83 isolates, GenBank KP142971 - KP142974). Valsa fabianae was the second most frequently isolated fungus after $N$. australe. It was isolated from 11 sites and the isolation frequency increased from the spring to the

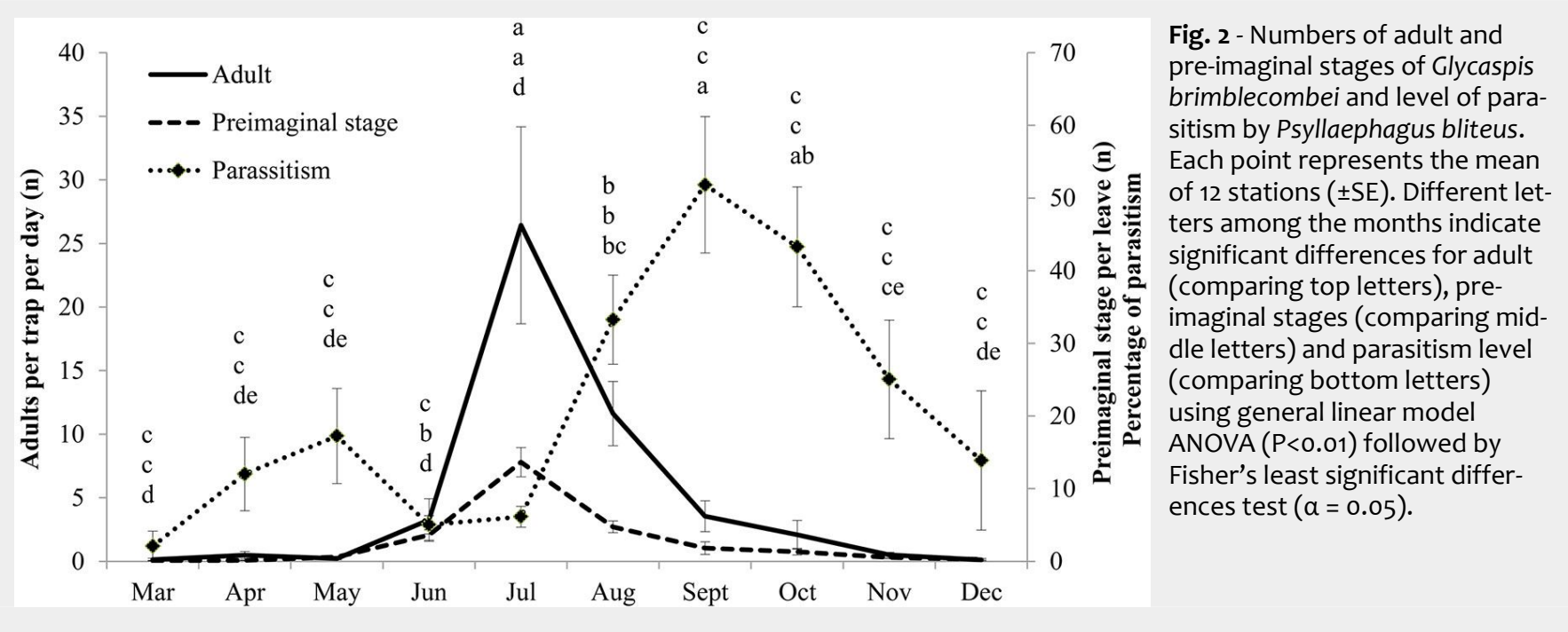


Fig. 3 - Major disease symptoms observed in Eucalyptus camaldulensis trees. (a-e):

Crown thinning, dieback of twigs and branches associated with an abnormal growth of epicormic shoots along stems and branches; (f, g): sunken bark cankers; (h): wood necrosis and discoloration visible after bark removal; (i): cross section of a branch showing a characteristic wedgeshaped necrotic sector in the wood; (j): colonies of Neofusicoccum australe growing on PDA following isolation from bark and wood chips.

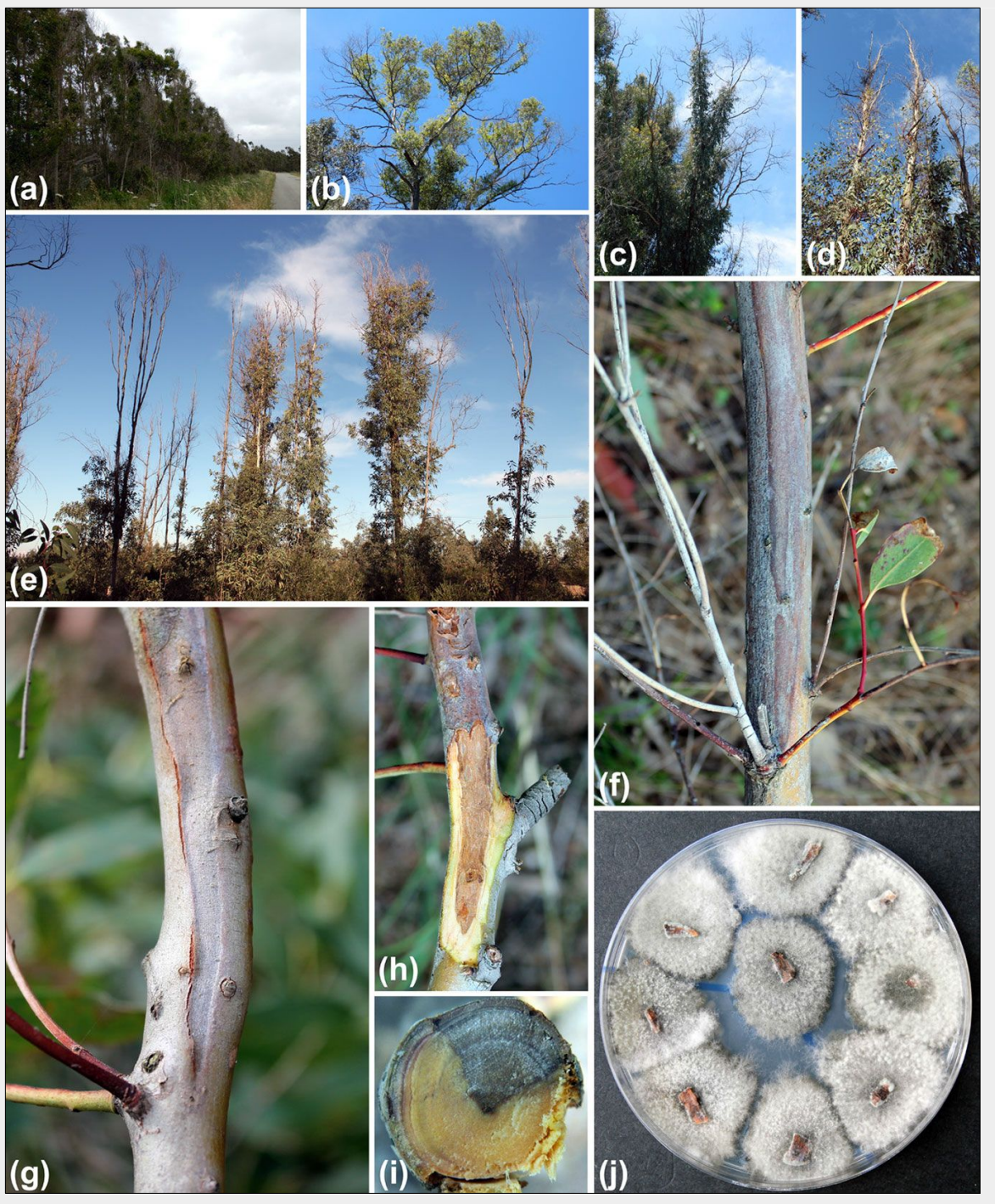

Tab. 2 - Isolation frequencies (\%) of fungal species at each survey site and season. (ns): no sample taken.

\begin{tabular}{|c|c|c|c|c|c|c|c|c|c|c|c|c|c|}
\hline \multirow{2}{*}{$\begin{array}{l}\text { Fungal } \\
\text { species }\end{array}$} & \multirow{2}{*}{$\begin{array}{l}\text { Sampling } \\
\text { period }\end{array}$} & \multicolumn{12}{|c|}{ Site } \\
\hline & & 1 & 2 & 3 & 4 & 5 & 6 & 7 & 8 & 9 & 10 & 11 & 12 \\
\hline \multirow{3}{*}{$\begin{array}{l}\text { Cytospora } \\
\text { sp.1 }\end{array}$} & Spring & - & 6.7 & - & 26.7 & - & 13.3 & - & - & - & - & - & - \\
\hline & Summer & - & - & - & - & - & - & - & - & - & - & - & ns \\
\hline & Autumn & - & - & - & - & - & - & - & - & - & - & - & ns \\
\hline \multirow{3}{*}{$\begin{array}{l}\text { Cytospora } \\
\text { sp. } 2\end{array}$} & Spring & - & - & - & - & 13.3 & - & 20 & - & - & - & - & - \\
\hline & Summer & - & - & - & - & - & - & - & - & - & - & - & ns \\
\hline & Autumn & - & - & - & - & - & - & - & - & - & - & - & ns \\
\hline \multirow{3}{*}{$\begin{array}{l}\text { Diaporthe } \\
\text { foeniculina }\end{array}$} & Spring & - & - & - & - & - & - & - & - & - & - & - & 20 \\
\hline & Summer & - & - & - & - & - & - & - & - & - & - & - & ns \\
\hline & Autumn & - & - & - & - & - & - & - & - & - & - & - & ns \\
\hline \multirow{3}{*}{$\begin{array}{l}\text { Neofusicoccum } \\
\text { australe }\end{array}$} & Spring & 46.7 & 93.3 & 80 & 46.7 & 66.7 & 46.7 & 53.3 & 100 & 80 & 80 & 100 & 80 \\
\hline & Summer & 66.7 & 40 & 40 & 86.7 & 60 & 73.3 & 53.3 & 93.3 & 80 & 80 & 93.3 & ns \\
\hline & Autumn & 53.3 & 26.7 & 66.7 & 46.7 & 80 & 46.7 & 46.7 & 93.3 & 26.7 & 40 & 93.3 & ns \\
\hline \multirow{3}{*}{$\begin{array}{l}\text { Neofusicoccum } \\
\text { luteum }\end{array}$} & Spring & - & - & - & - & - & - & - & - & - & - & - & - \\
\hline & Summer & - & 26.7 & - & - & - & - & - & - & 20 & - & - & ns \\
\hline & Autumn & - & 6.7 & - & 6.7 & - & 6.7 & - & 6.7 & 6.7 & 6.7 & 6.7 & ns \\
\hline \multirow{3}{*}{$\begin{array}{l}\text { Neofusicoccum } \\
\text { mediterraneum }\end{array}$} & Spring & - & - & - & - & 6.7 & - & - & - & - & 20 & - & - \\
\hline & Summer & 20 & - & - & - & - & 7 & - & - & - & 20 & - & ns \\
\hline & Autumn & - & - & - & 40 & - & 20 & - & - & - & - & - & ns \\
\hline \multirow{3}{*}{$\begin{array}{l}\text { Neofusicoccum } \\
\text { parvum }\end{array}$} & Spring & - & - & - & - & - & - & - & - & - & - & - & - \\
\hline & Summer & 6.77 & - & - & - & 26.7 & - & - & - & - & - & - & ns \\
\hline & Autumn & - & - & - & - & 6.7 & - & - & - & - & - & - & ns \\
\hline \multirow{3}{*}{$\begin{array}{l}\text { Neofusicoccum } \\
\text { vitifusiforme }\end{array}$} & Spring & 40 & - & - & 26.7 & - & - & - & - & - & - & - & - \\
\hline & Summer & - & - & - & 13.3 & - & - & - & - & - & - & - & ns \\
\hline & Autumn & - & - & - & - & - & - & - & - & - & - & - & ns \\
\hline \multirow{3}{*}{$\begin{array}{l}\text { Valsa } \\
\text { fabianae }\end{array}$} & Spring & - & - & - & - & - & 13.3 & - & - & - & - & - & - \\
\hline & Summer & - & 46.7 & 60 & - & - & 20 & 46.7 & 6.7 & - & - & 6.7 & ns \\
\hline & Autumn & 46.7 & 66.7 & 33.3 & 6.7 & 13.3 & 26.7 & 53.3 & - & 66.7 & 53.3 & - & ns \\
\hline
\end{tabular}


Tab. 3 - Mean lesion area \pm standard error (SE) caused by fungal species on Eucalyptus camaldulensis trees. (1): Values within column followed by the same letter do not significantly differ according to Fisher's least significant differences multiple range test $(P<0.05)$. (2): Number of samples from which the fungus was re-isolated out of 10 samples per tree examined.

\begin{tabular}{lcrc}
\hline Species & Isolate & $\begin{array}{c}\text { Mean lesion area } \\
\left(\mathbf{c m}^{2}\right) \pm \mathrm{SE}^{1}\end{array}$ & Reisolation \\
\hline Cytospora sp. 1 & CAD049 & $3.23 \pm 0.22 \mathrm{~d}$ & 60 \\
Cytospora sp. 2 & CAD050 & $1.95 \pm 0.17 \mathrm{~d}$ & 60 \\
Diaporthe foeniculina & CAD051 & $1.55 \pm 0.09 \mathrm{~d}$ & 60 \\
Neofusicoccum australe & CAD028 & $8.90 \pm 1.50 \mathrm{c}$ & 60 \\
Neofusicoccum luteum & CAD029 & $18.61 \pm 1.67 \mathrm{~b}$ & 60 \\
Neofusicoccum mediterraneum & CAD026 & $25.25 \pm 1.98 \mathrm{a}$ & 60 \\
Neofusicoccum parvum & CAD025 & $11.08 \pm 3.32 \mathrm{C}$ & 60 \\
Neofusicoccum vitifusiforme & CAD027 & $2.14 \pm 0.12 \mathrm{~d}$ & 60 \\
Valsa fabianae & CAD052 & $1.38 \pm 0.09 \mathrm{~d}$ & 60 \\
Control & - & $1.53 \pm 0.04 \mathrm{~d}$ & - \\
\hline
\end{tabular}

autumn sampling. The other three species were isolated at a relatively low frequency from one or a few surveyed sites and only during the spring (Tab. 2).

\section{Pathogenicity tests}

The pathogenicity tests highlighted significant differences in aggressiveness among the nine species obtained from branch cankers (Tab. 3). All the Neofusicoccum species except $N$. vitifusiforme proved to be aggressive pathogens on $E$. camaldulensis. At the end of the experimental period, all trees inoculated with $\mathrm{N}$. australe, N. luteum, N. mediterraneum or N. parvum displayed dark brown bark lesions that spread up and down the trunk from the inoculation site and also penetrated a few millimeters into the wood. The average lesion size differed significantly according to the species, e.g., the lesions caused by N. mediterraneum (mean $=25.25 \mathrm{~cm}^{2}$ ) were significantly larger than those caused by N. luteum (mean $\left.=18.61 \mathrm{~cm}^{2}\right)$, N. parvum (mean $=11.08 \mathrm{~cm}^{2}$ ) and $\mathrm{N}$. australe (mean $=8.9$ $\mathrm{cm}^{2}$ ). All the other fungal pathogens caused small necrotic lesions confined to the inoculation point with no statistically significant difference from the control inoculations. All the fungal species were successfully re-isolated from symptomatic wood and inner bark tissues from all inoculated trees (Tab. 3).

\section{Discussion}

This study describes the first survey of pests and diseases threatening E. camaldulensis plantations in Sardinia. Our results have characterized the population dynamics of the principal insect pest, G. brimblecombei, and have clarified the symptomatology and etiology of the severe decline affecting this species. In particular, our data revealed that $G$. brimblecombei infestations have assumed epidemic proportions at all 12 survey sites and that this pest currently represents the main entomological threat to $E$. camaldulensis plantations in Sardinia. Its natural enemy $P$. bliteus was also found at each site, but was not suffi- cient to limit the population increase of $G$. brimblecombei which started in May.

Morphological analysis and DNA sequencing revealed nine different fungal species in V-shaped cankers, including $D$. foeniculina, $N$. australe, $N$. luteum, $N$. mediterraneum, N. parvum, N. vitifusiforme, V. fabianae and two putative new species of the genus Cytospora.

Neofusicoccum species accounted for more than $80 \%$ of the isolates, making this by far the most common genus associated with branch cankers in declining Sardinian E. camaldulensis trees. Almost all the Neofusicoccum species we identified have previously been detected on eucalyptus trees (Gezahgne et al. 2004, Barber et al. 2005, Burgess et al. 2005, Crous et al. 2007a) with the exception of $N$. luteum, which is presented here as a eucalypt pathogen for the first time.

Neofusicoccum australe was the most frequently isolated fungal species, and our field survey and pathogenicity test data clearly revealed that it is the major cause of stem and branch canker in Sardinian E. camaldulensis plantations. The high frequency of $N$. australe agrees with earlier studies conducted in native eucalypt forests, where the dominance of this pathogen prompted the hypothesis that it is native to the southern hemisphere (Burgess et al. 2005, 2006a). In Italy, N. australe was previously reported in association with olive (Olea europaea L.) drupe rot, declining grapevine (Vitis vinifera L.) plants and declining juniper trees (Lazzizera et al. 2008, Andolfi et al. 2012, Linaldeddu et al. 2015a). The other four Neofusicoccum species were isolated at a lower frequency and from only a few sites. Neofusicoccum luteum was previously isolated from eucalypts in Australia by Smith \& Stanosz (2001). However, the definitive identification of Botryosphaeriaceae species was challenging in the past and more than one species has erroneously been described as $N$. luteum over the years. When the ITS sequence of isolate $96-130$ (= ATCC56125) studied by Smith \& Stanosz (2001) was used as a BLAST query, we found 100\% identity with sequences from the ex-type culture of N. australe (AY339262), suggesting that the isolate is $N$. australe rather than $N$. luteum. Although the importance of $N$. luteum as a eucalypt pathogen is unclear, it infects a wide range of fruit and forest trees worldwide (McDonald et al. 2009, Adesemoye et al. 2013, Barradas et al. 2013) and has recently been isolated from declining tree heath (Erica arborea L.) shrubs in their natural range in Sardinia (Linaldeddu et al. 2015b).

Neofusicoccum mediterraneum was originally isolated from eucalypts in Greece (Crous et al. 2007a) but was later identified as an aggressive pathogen of olive drupes in southern Italy, grapevine and English walnut (Juglans regia L.) in California (Lazzizera et al. 2008, Trouillas et al. 2010, UrbezTorres et al. 2010). To our knowledge, this is the first report of this pathogen in Sardinia. In the pathogenicity tests, N. mediterraneum was the most aggressive species, but because it was only found at a few of the survey sites its impact is marginal compared to that of $\mathrm{N}$. australe.

Neofusicoccum parvum is emerging as a common and cosmopolitan species on diverse host plants, and is now recognized as an aggressive pathogen of grapevine (Urbez-Torres 2011), mango (Mangifera indica L. - Marques et al. 2013) and walnut (Cheon et al. 2013). Neofusicoccum parvum is known to infect several eucalypt species including E. globulus, E. grandis W. Hill ex Maiden and E. saligna Sm. (Gezahgne et al. 2004), E. pellita F. Muell (Barber et al. 2005) and E. urophylla S.T. Blake (Mohali et al. 2007). In particular, Gezahgne et al. (2004) found that N. parvum is the major cause of botryosphaeria canker in Ethiopian eucalypt plantations. In our investigation, $\mathrm{N}$. parvum was isolated only sporadically from our field sites suggesting it has only a marginal role in the etiology of the decline of Sardinian E. camaldulensis plantations. However, it is interesting to note that only the trees artificially inoculated with $\mathrm{N}$. parvum showed copious exudations of kino gum at the end of the experimental period. Neofusicoccum vitifusiforme was originally thought to be restricted to grapevine (Van Niekerk et al. 2004), but it was later isolated from olive (Lazzizera et al. 2008), peach (Prunus persica [L.] Batsch), Chinese plum (Prunus salicina Lindl. - Damm et al. 2007) and the northern highbush blueberry (Vaccinium corymbosum L.) (Kong et al. 2010). Furthermore, both Lazzizera et al. (2008) and Phillips et al. (2013) showed that $\mathrm{N}$. vitifusiforme is phylogenetically indistinguishable from Dichomera eucalypti (G. Winter) B. Sutton, and have suggested that $D$. eucalypti is the synanamorph of $N$. vitifusiforme. Eucalyptus spp. can therefore be regarded as additional hosts for $\mathrm{N}$. vitifusiforme. Although the plurivorous nature of $N$. vitifusiforme has now been established, there are still conflicting reports regarding its pathogenicity. In particular, it 
has been reported as an aggressive pathogen of grapevine and olive drupes in Italy, apple (Malus domestica Borkh.) in South Africa and blueberry in China (Lazzizera et al. 2008, Kong et al. 2010, Cloete et al. 2011, Mondello et al. 2013), as a weak pathogen of grapevine in South Africa and E. globulus in Australia (Van Niekerk et al. 2004, Burgess et al. 2005) and as nonpathogenic on grapevine and pear trees (Pyrus spp.) in South Africa by Cloete et al. (2011). In our study, only four of the nine isolated species were pathogenic on $E$. camaldulensis as judged by the formation of necrotic lesions that were significantly larger than controls. The pathogenicity tests therefore suggest that $N$. vitifusiforme, together with $D$. foeniculina, V. fabianae and the two unidentified Cytospora species, could represent a component of the endophytic eucalypt mycoflora.

The genus Diaporthe (teleomorph of Phomopsis) includes a great number of endophytic, saprotrophic and phytopathogenic fungi from a wide range of woody and herbaceous hosts (Gomes et al. 2013). In this study, D. foeniculina was isolated with a relatively low frequency at a single survey site and only during the spring. This represents the first report of the species on $E$. camaldulensis.

Eucalyptus spp. are known to host a large number of species of Cytospora and their Valsa teleomorphs, some of which are thought to cause stem cankers. These genera have a long and confusing taxonomic history because species identification was initially based solely on morphological features. The phylogenetic analysis of different genomic regions has prompted the taxonomic reassessment of many species within these genera (Adams et al. 2005). We isolated two species of Cytospora (here reported as Cytospora species 1 and 2) with low frequencies at a small number of sites, and solely in the spring samples. We have not named these species because further investigation is necessary to achieve the unequivocal identification of these taxa. Valsa fabianae (anamorph Cytosporaeuca lypticola van der Westh.) was recently isolated from cankered and dead branches of several Eucalyptus species in Australia, Uganda and South Africa (Adams et al. 2005). More recently, this species was isolated from symptomatic and asymptomatic leaves of $E$. globulus trees affected by MLD in Spain (Sánchez Márquez et al. 2011). In our study, V. fabianae was isolated from 11 sites and the isolation frequency increased from the spring to the autumn.

\section{Conclusions}

Our results have shown that N. australe is the main pathogen associated with cankers and branch dieback in Sardinian E. camaldulensis plantations. The high frequency of trees at different life stages with cankers on their stems and branches, as well as fresh exudates of kino gum, suggests that the disease is still in its epidemic phase. Abiotic factors that may facilitate the outbreak of $N$. australe infections remain unknown, as well as potential synergistic interactions with other Neofusicoccum species and plant stress caused by $G$. brimblecombei. Our data, together with the results of previous studies on the etiology of decline affecting holm oak (Quercus ilex L.), narrow-leaved ash (Fraxinus angustifolia Vahl) and Phoenician juniper (Juniperus phoenicea L. - Linaldeddu et al. 2011, 2014, Alves et al. 2014), emphasize how fungal species in the Botryosphaeriaceae family represent a growing threat to forest ecosystems in Sardinia.

\section{Acknowledgements}

This study was financially supported by the "Regione Autonoma Sardegna, Tavolo Tecnico Difesa Fitosanitaria Piante Forestali, Assessorato Difesa Ambiente - Servizio Tutela del suolo e politiche forestali" in the context of the research project "Programma triennale di controllo biologico della Psilla lerp dell'eucalipto Glycaspis brimblecombei e monitoraggio delle problematiche fitosanitarie dell'eucalipto in Sardegna", coordinated by Prof. Ignazio Floris, University of Sassari, Italy. Franco Buffa and Antonio Deidda gratefully acknowledge the Sardinian Regional Government for the financial support of their PhD scholarships. Bruno Scanu acknowledges the Sardinian Regional Government for the financial support of the research project "P.O.R. Sardegna F.S.E. Operational Programme of the Autonomous Region of Sardinia, European Social Fund 2007-2013 - Axis IV Human Resources, Objective I.3, Line of Activity I.3.1". The authors would like to thank Dr. Richard M Twyman for English language editing.

\section{References}

Adams GC, Wingfield MJ, Common R, Roux J (2005). Phylogenetic relationships and morphology of Cytospora species and related teleomorphs (Ascomycota, Diaporthales, Valsaceae) from Eucalyptus. Studies in Mycology 52: 1-144.

Adesemoye AO, Mayorquin JS, Wang DH, Twizeyimana M, Lynch SC, Eskalen A (2013). Identification of species of Botryosphaeriaceae causing Bot gummosis in Citrus in California. Plant Disease 98: 55-61. - doi: 10.1094/PDIS-05-13-0492RE

Alves A, Crous PW, Correia A, Phillips AJL (2008). Morphological and molecular data reveal cryptic species in Lasiodiplodia theobromae. Fungal Diversity 28: 1-13. [online] URL: http://www. researchgate.net/publication/40095352

Alves A, Linaldeddu BT, Deidda A, Scanu B, Phillips AJL (2014). The complex of Diplodia species associated with Fraxinus and some other woody hosts in Italy and Portugal. Fungal Diversity 67: 143-156. - doi: 10.1007/s13225-0140282-9

Andolfi A, Maddau L, Cimmino A, Linaldeddu BT, Franceschini A, Serra S, Basso S, Melck D, Evidente A (2012). Cyclobotryoxide, a phytotoxic metabolite produced by the plurivorous pathogen Neofusicoccum australe. Journal of Nat- ural Products 75 (10): 1785-1791. - doi: 10.1021/ np300512m

Barber PA, Burgess TI, Keane PJ, Hardy GESJ, Slippers B, Wingfield MJ (2005). Botryosphaeria species from Eucalyptus in Australia are pleoanamorphic, producing Dichomera synanamorphs in culture. Mycological Research 109: 1347-1363. - doi: 10.1017/S0953756205003989 Barradas C, Correia A, Alves A (2013). First report of Neofusicoccum australe and N. luteum associated with canker and dieback of Quercus robur in Portugal. Plant Disease 97: 560.

Bella S, Rapisarda C (2013). First record from Greece of the invasive red gum lerp psyllid Glycaspis brimblecombei Moore (Hemiptera: Psyllidae) and its associated parasitoid Psyllaephagus bliteus Riek (Hymenoptera: Encyrtidae). Redia 96: 33-35. [online] URL: http://cra-jour nals.cineca.it/index.php/redia/article/view/762 Ben Attia S, Rapisarda C (2014). First record of the red gum lerp psyllid, Glycaspis brimblecombei Moore (Hemiptera Psyllidae), in Tunisia. Phytoparasitica 42: 535-539. - doi: 10.1007/s12 600-014-0391-8

Boggia L (1987). Conclusioni sull'eucalitticoltura nazionale [Conclusion on the national eucalypt plantations]. Cellulosa e Carta 5: 11-17. [in Italian]

Branco $M$, Bragança $H$, Sousa E, Phillips AJL (2014). Pests and diseases in Portuguese forestry: current and new threats. In: "Forest context and policies in Portugal. Present and Future Challenges" (Reboredo F ed). World Forests 19: 117-154. - doi: 10.1007/978-3-319-08455$8 \_5$

Brennan EB, Gill R (1999). First record of Glycaspis brimblecombei Moore (Homoptera: Psyllidae) in North America: Initial observations and predator associations of a potential serious new pest of Eucalyptus in California. Pan-Pacific Entomologist 75: 55-57. [online] URL: http://w ww.cabdirect.org/abstracts/19991108536.html Brennan EB, Hrusa GF, Weinbaum SA, Levison Jr W (2001). Resistance of Eucalyptus species to Glycaspis brimblecombei (Homoptera: Psyllidae) in the San Francisco Bay area. Pan-Pacific Entomologist 77: 249-253. [online] URL: http:// www.cabdirect.org/abstracts/20023019598.ht $\mathrm{ml}$

Brooker MIH (2000). A new classification of the genus Eucalyptus L'Her. (Myrtaceae). Australian Systematic Botany 13 (1): 79-148. - doi: 10.1071/SB98008

Buffa F (2015). Problematiche entomologiche dell'eucalipto in Sardegna e monitoraggio del fitofago di nuova introduzione Psylla lerp (Glycaspis brimblecombei) [Entomological problems of eucalypt in Sardinia and monitoring of the newly introduced phytophagous Psilla lerp (Glycaspis brimblecombei)]. PhD thesis, Department of Agriculture, University of Sassari, Sassari, Italy, pp. 78. [in Italian]

Burgess TI, Barber PA, Hardy GES (2005). Botryosphaeria spp. associated with eucalypts in Western Australia, including the description of Fusicoccum macroclavatum sp. nov. Australasian Plant Pathology 34: 557-567. - doi: 10.1071/ AP05073

Burgess TI, Sakalidis ML, Hardy GES (2006a). Gene flow of the canker pathogen Botryosphaeria australis between Eucalyptus globulus 
plantations and native eucalypt forests in Western Australia. Austral Ecology 31: 559-566. - doi: 10.1111/j.1442-9993.2006.01596.x

Burgess TI, Barber PA, Mohali S, Pegg G, De Beer W, Wingfield MJ (2006b). Three new Lasiodiplodia spp. from the tropics, recognized based on DNA sequence comparisons and morphology. Mycologia 98 (3): 423-435. - doi: 10.3852/mycologia.98.3.423

Caleca V, Lo Verde G, Maltese M (2011). First record in Italy of Psyllaephagus bliteus Riek (Hymenoptera Encyrtidae) parasitoid of Glycaspis brimblecombei Moore (Hemiptera Psyllidae). Naturalista siciliano 2011: 435-444. [online] URL: http://orgprints.org/20564/

Cheon W, Kim YS, Lee SG, Jeon YH, Chun IJ (2013). First report of branch dieback of walnut caused by Neofusicoccum parvum in Korea. Plant Disease 97 (8): 1114.

Cloete M, Fourie PH, Damm U, Crous PW, Mostert L (2011). Fungi associated with dieback symptoms of apple and pear trees with a special reference to grapevine trunk disease pathogens. Phytopathologia Mediterranea 50 (supplement): 176-190. [online] URL: http:// www.fupress.net/index.php/pm/article/view/90 04

Coutinho TA, Wingfield MJ, Alfenas AC, Crous PW (1998). Eucalyptus rust: a disease with the potential for serious international implications. Plant Disease 82: 819-825. - doi: 10.1094/PDIS. 1998.82.7.819

Crous PW, Wingfield MJ (1997). New species of Mycosphaerella occurring on Eucalyptus leaves in Indonesia and Africa. Canadian Journal of Botany 75: 781-790. - doi: 10.1139/b97-088

Crous PW, Groenewald JZ, Wingfield MJ, Phillips AJL (2007a). Neofusicoccum mediterraneum. Fungal Planet 19: 2.

Crous PW, Braun U, Groenewald JZ (2007b). Mycosphaerella is polyphyletic. Studies in Mycology 58: 1-32. - doi: 10.3114/sim.2007.58.01

Daane KM, Sime KR, Dahlsten DL, Andrews Jr JW, Zuparko RL (2005). The biology of Psyllaephagus bliteus Riek (Hymenoptera: Encyrtidae), a parasitoid of the red gum lerp psyllid (Hemiptera: Psylloidea). Biological Control 32: 228-235. - doi: 10.1016/j.biocontrol.2004.09.015 Damm U, Crous PW, Fourie PH (2007). Botryosphaeriaceae as potential pathogens of Prunus in South Africa, with descriptions of Diplodia africana and Lasiodiplodia plurivora sp. nov. Mycologia 99: 664-680. - doi: 10.3852/ mycologia.99.5.664

EPPO (2006). First report of two new eucalyptus pests in the south of France: Ophelimus maskelli and Leptocybe invasa. European and Mediterranean Plant Protection Organization, EPPO Reporting Service 9: 9.

Flynn B (2010). Eucalyptus: having an impact on the global solid wood industry. Wood Resources International, Web site. [online] URL: http://www.wri-ltd.com/marketPDFs/Eucalyptu s.pdf

Gezahgne A, Roux J, Slippers B, Wingfield MJ (2004). Identification of the causal agent of Botryosphaeria stem canker in Ethiopian Eucalyptus plantations. South African Journal of Botany 70: 241-248. - doi: 10.1016/S0254-6299 (15)30241-6

Gomes RR, Glienke C, Videira SIR, Lombard L,
Groenewald JZ, Crous PW (2013). Diaporthe: a genus of endophytic, saprobic and plant pathogenic fungi. Persoonia 31: 1-41. - doi: 10.3767/ 003158513 X666844

Gryzenhout M, Myburg H, Van Der Merwe NA, Wingfield BD, Wingfield MJ (2004). Chrysoporthe, a new genus to accommodate Cryphonectria cubensis. Studies in Mycology 50: 119142. [online] URL: http://www.fabinet.up.ac. za/publication/pdfs/648-2004

Inderbitzin P, Bostock RM, Trouillas FP, Michailides TJ (2010). A six-locus phylogeny reveals high species diversity in Botryosphaeriaceae from California almond. Mycologia 102: 1350-1368. - doi: 10.3852/10-006

Kong CS, Qiu XL, Yi KS, Yu XF (2010). First report of Neofusicoccum vitifusiforme causing Blueberry blight of blueberry in China. Plant Disease 94: 13732-13732. - doi: 10.1094/PDIS-05-10-0393

Lamari L (2002). Assess: image analysis software for plant disease quantification. APS Press, St Paul, MN, USA.

Laudonia S, Garonna AP (2010). The red gum lerp psyllid, Glycaspis brimblecombei, a new exotic pest of Eucalyptus camaldulensis in Italy. Bulletin of Insectology 63: 233-236. [online] URL: http://www.researchgate.net/publication/2284 93158

Lazzizera C, Frisullo S, Alves A, Phillips AJL (2008). Morphology, phylogeny and pathogenicity of Botryosphaeria and Neofusicoccum species associated with drupe rot of olives in southern Italy. Plant Pathology 57: 948-956. doi: 10.1111/j.1365-3059.2008.01842.x

Linaldeddu BT, Scanu B, Maddau L, Franceschini A (2011). Diplodia africana causing dieback disease on Juniperus phoenicea: a new host and first report in the northern hemisphere. Phytopathologia Mediterranea 50 (3): 473-477.

Linaldeddu BT, Franceschini A, Alves A, Phillips AJL (2013). Diplodia quercivora sp. nov.: a new species of Diplodia found on declining Quercus canariensis trees in Tunisia. Mycologia 105 (5): 1266-1274. - doi: 10.3852/12-370

Linaldeddu BT, Scanu B, Maddau L, Franceschini A (2014). Diplodia corticola and Phytophthora cinnamomi: the main pathogens involved in holm oak decline on Caprera island (Italy). Forest Pathology 44: 191-200. - doi: 10.1111/efp.12 081

Linaldeddu BT, Deidda A, Scanu B, Franceschini A, Serra S, Berraf-Tebbal A, Zouaoui Boutiti M, Ben Jama ML, Phillips AJL (2015a). Diversity of Botryosphaeriaceae species associated with grapevine and other woody hosts in Italy, Algeria and Tunisia, with descriptions of Lasiodiplodia exigua and Lasiodiplodia mediterranea sp. nov. Fungal Diversity 71: 201-2014. - doi: 10.1007/ s13225-014-0301-X

Linaldeddu BT, Scanu B, Seddaiu S, Deidda A, Maddau L, Franceschini A (2015b). A new disease of Erica arborea in Italy caused by Neofusicoccum luteum. Phytopathologia Mediterranea 54 (1): 124-127. [online] URL: http:// search.proquest.com/openview/e7eb5e3f7cob 6667974202182170e5co/1

Lundquist JE, Purnell RC (1987). Effects of Mycosphaerella leaf spot on growth of Eucalyptus nitens. Plant Disease 71 (11): 1025-1029. - doi: 10.1094/PD-71-1025

Marques MW, Lima NB, De Morais MA, Barbosa
MA, Souza BO, Michereff SJ, Phillips AJ, C'mara MP (2013). Species of Lasiodiplodia associated with mango in Brazil. Fungal Diversity 61 (1): 181-193. - doi: 10.1007/s13225-013-0231-z

McDonald V, Lynch S, Eskalen A (2009). First report of Neofusicoccum australe, N. luteum, and N. parvum associated with avocado branch canker in California. Plant Disease 93: 967. [online] URL: http://www.researchgate.net/publica tion/249305756

McKinnon GE, Vaillancourt RE, Steane DA, Potts BM (2008). An AFLP marker approach to lowerlevel systematics in Eucalyptus (Myrtaceae). American Journal of Botany 95: 368-380. - doi: 10.3732/ajb.95.3.368

Mercurio R, Minotta G (2000). Arboricoltura da legno [Arboriculture for wood production]. Ed. Clueb, Bologna, Italy, pp. 203. [in Italian]

Mohali S, Burgess TI, Wingfield MJ (2005). Diversity and host association of the tropical tree endophyte Lasiodiplodia theobromae revealed using simple sequence repeat markers. Forest Pathology 35: 385-396. - doi: 10.1111/j.1439-0329. 2005.00418.x

Mohali SR, Slippers B, Wingfield MJ (2007). Identification of Botryosphaeriaceae from Eucalyptus, Acacia and Pinus in Venezuela. Fungal Diversity 25: 103-125. [online] URL: http://www. fabinet.up.ac.za/publication/pdfs/303-2007

Mondello V, Lo Piccolo S, Conigliaro G, Alfonzo A, Torta L, Burruano S (2013). First report of Neofusiccoccum vitifusiforme and presence of other Botryosphaeriaceae species associated with Botryosphaeria dieback of grapevine in Sicily (Italy). Phytopathologia Mediterranea 52: 388-396. [online] URL: http://www.fupress.net/ index.php/pm/article/view/12328

Old KM, Gibbs R, Craig I, Myers BJ, Yaun ZQ (1990). Effect of drought and defoliation on the susceptibility of Eucalyptus to cankers caused by Endothia gyrosa and Botryosphaeria ribis. Australian Journal of Botany 38: 571-581. - doi: 10.1071/BT9900571

Ohmart CP, Edwards PB (1991). Insect herbivory on Eucalyptus. Annual Reviews of Entomology 36: 637-657. - doi: 10.1146/annurev.en.36.010191. 003225

Paine TD, Dahlsten DL, Millar JG, Hoddle MS, Hanks LM (2000). UC scientists apply IPM techniques to new eucalyptus pests. California Agriculture 54: 8-13. - doi: 10.3733/ca.v054no6p8

Paine TD, Millar JG (2002). Insect pests of eucalypts in California: implications of managing invasive species. Bulletin of Entomological Research 92: 147-151. - doi: 10.1079/BER2002151

Phillips AJ, Alves A, Abdollahzadeh J, Slippers B, Wingfield MJ, Groenewald JZ, Crous PW (2013). The Botryosphaeriaceae: genera and species known from culture. Studies in Mycology 76: 51-167. - doi: 10.3114/simoo21

Reguia K, Peris-Felipo FJ (2013). Glycaspis brimblecombei Moore, 1964 (Hemiptera Psyllidae) invasion and new records in the Mediterranean area. Biodiversity Journal 4 (4): 501-506. [online] URL: http://www.researchgate.net/publi cation/263086791

Roux J, Coutinho TA, Mujuni Byabashaija D, Wingfield MJ (2001). Diseases of plantation Eucalyptus in Uganda. South African Journal of Science 97: 16-18.

Roux J, Wingfield MJ (2009). Ceratocystis spe- 
cies: emerging pathogens of non-native plantations Eucalyptus and Acacia species. Southern Forests 71 (2): 115-120. - doi: 10.2989/SF.2009. 71.2.5.820

Sánchez Márquez S, Bills GF, Zabalgogeazcoa I (2011). Fungal species diversity in juvenile and adult leaves of Eucalyptus globulus from plantations affected by Mycosphaerella leaf disease. Annals of Applied Biology 158: 177-187. - doi: 10.1111/j.1744-7348.2010.00449.x

Sharma JK, Mohanan C, Maria Florence EJ (1984). A new stem canker disease of Eucalyptus caused by Botryodiplodia theobromae in India. Transactions of the British Mycological Society 83: 162-163. - doi: 10.1016/So007-1536 (84)80261-2

Sharma A, Raman A, Taylor G, Murray Fletcher M (2013). Nymphal development and lerp construction of Glycaspis sp. (Hemiptera: Psylloidea) on Eucalyptus sideroxylon (Myrtaceae) in central-west New South Wales, Australia. Arthropod Structure and Development 42: 55564. - doi: 10.1016/j.asd.2013.07.005

Slippers B, Fourie G, Crous PW, Coutinho TA, Wingfield $B D$, Carnegie $A J$, Wingfield $M J$ (2004). Speciation and distribution of Botryosphaeria spp. on native and introduced Eucalyptus trees in Australia and South Africa. Studies in Mycology 50: 343-358. [online] URL: http:// s3.amazonaws.com/academia.edu.documents/ 42790005/

Slippers B, Burgess T, Pavlic D, Ahumada R, Maleme $\mathrm{H}$, Mohali S, Rodas C, Wingfield MJ (2009). A diverse assemblage of Botryosphaeriaceae infect Eucalyptus in native and non-native environments. Southern Forests 71: 101-110. - doi: 10.2989/SF.2009.71.2.3.818

Smith H, Kemp GHJ, Wingfield MJ (1994). Canker and dieback of Eucalyptus in South Africa caused by Botryosphaeria dothidea. Plant Pathology 43: 1031-1034. - doi: 10.1111/j.1365-3059. 1994.tbo1653.x

Smith DR, Stanosz GR (2001). Molecular and morphological differentiation of Botryosphaeria dothidea (anamorph Fusicoccum aesculi) from some other fungi with Fusicoccum anamorphs. Mycologia 93 (3): 505-515. - doi: $10.2307 / 3761736$

Spodek M, Burckhardt D, Protasov A, Mendel Z (2015). First record of two invasive eucalypt psyllids (Hemiptera: Psylloidea) in Israel. Phytoparasitica 43 (3): 401-406. - doi: 10.1007/s12 600-015-0465-2

Tamesse JL, Soufo L, Wenceslas Y, Dzokou VJ (2010). First record of Blastopsylla occidentalis Taylor, 1985 (Hemiptera: Psyllidae), a Eucalyptus psyllid in Cameroon, Central Africa. Entomological Research 40 (4): 211-216. - doi: 10.1111/j. 1748-5967.2010.00285.x

Trouillas FP, Urbez-Torres JR, Peduto F, Gubler WD (2010). First report of twig and branch dieback of English walnut (Juglans regia) caused by Neofusicoccum mediterraneum in California. Plant Disease 94: 1267. - [online] URL: http://apsjournals.apsnet.org/doi/abs/10.1094/P DIS-06-10-0412

Urbez-Torres JR, Peduto F, Gubler WD (2010). First report of grapevine cankers caused by Lasiodiplodia crassispora and Neofusicoccum mediterraneum in California. Plant Disease 94: 785. [online] URL: http://apsjournals.apsnet.org/doi/ abs/10.1094/PDIS-94-6-0785B
Urbez-Torres JR (2011). The status of Botryosphaeriaceae species infecting grapevines. Phytopathologia Mediterranea 50: S5-S45. [online] URL: http://www.fupress.net/index.php/pm/arti cle/view/9316

Van Niekerk JM, Crous PW, Groenewald JZ, Fourie PH, Halleen F (2004). DNA phylogeny, morphology and pathogenicity of Botryosphaeria species on grapevines. Mycologia 96: 781-798. - doi: 10.2307/3762112

Webb RS (1983). Seed capsule abortion and twig dieback of Eucalyptus camaldulensis in South Florida induced by Botryosphaeria ribis. Plant Disease 67: 108-109. - doi: 10.1094/PD-67-108

White TJ, Bruns T, Lee S, Taylor J (1990). Amplification and direct sequencing of fungal ribosomal RNA genes for phylogenies. In: "PCR protocols: A guide to methods and applications" (Innis MA, Gelfand DH, Sninsky JJ, White TJ eds). Academic Press, San Diego, CA, USA, pp. 315-322.

Wilcken CF, Soliman EP, Nogueira De Sá LA, Barbosa LR, Dias TKR, Ferreira-Filho PJ, Oliveira RJR (2010). Bronze bug Thaumastocoris peregrinus Carpintero and Dellapé (Hemiptera: Thaumastocoridae) on Eucalyptus in Brazil and its distribution. Journal of Plant Protection Research 50 (2): 201-205. - doi: 10.2478/v10045-01 0-0034-0

Wingfield MJ, Slippers B, Hurley BP, Coutinho TA, Wingfield BD, Roux J (2008). Eucalypt pests and diseases: growing threats to plantation productivity. Southern Forests 70: 139-144. doi: 10.2989/SOUTH.FOR.2008.70.2.9.537 